\title{
SEJARAH PENDIDIKAN ISLAM PADA MASSA DINASTI FATIMIYAH DI MESIR (909-1171 M)
}

\author{
Oleh: \\ Muhammad \\ STKIP Taman Siswa Bima \\ muhammadqu@gmail.com
}

\begin{abstract}
Abstrak:
Dinasti Fatimiyah termasuk Dinasti Syi'ah yang didirikan oleh Ubaidillah Al-Mahdi. Dinasti ini berkuasa dari tahun 909 M sampai dengan tahun 1171 M., atas dasar legitimasi klaim keturunan Nabi lewat Fahtimah dan Ali bin Abi Thalib dari Ismail anak Jafar Sidik. Dinasti ini didirikan sebagai tandingan bagi penguasa dunia muslim saat itu yang terpusat di Bagdad, yaitu Bani Abbasiyah. Wilayah kekuasaan Dinasti Fatimiyah meliputi Afrika Utara, Mesir, dan Suriah. Berdirinya Dinasti Fatimiyah dilatarbelakangi oleh melemahnya Dinasti Abbasiyah. Pada masa Dinasti Fatimiyah, lembaga pendidikan yang digunakan sebagai basis pengembangan pendidikan terdiri dari; Masjid, Istana, Perpusakaan dan Dar al-'Ilm atau biasa disebut Jamiah Ilmiyah Akademi (lembaga riset). Perkembangan ilmu pengetahuan pada masa Dinasti Fatimiyah meliputi beberapa bidang ilmu seperti; Bahasa dan Sastra, Ilmu Kedokteran, Syair dan Filsafat. Berkenaan dengan hal tersebut, universitas Al-azhar merupakan lembaga pendidikan tinggi, sekaligus menjadi bukti sejarah peradaban Dinasti Fatimiyah dalam pengembangan pendidikan, dan sampai sekarang menjadi kiblat pendidikan yang bernuansa Islam.
\end{abstract}

Kata Kunci: Sejarah, Pendidikan Islam, Dinasti Fatimiyah.

\section{Pendahuluan}

Pendidikan merupakan bagian terpenting yang tidak terpisahkan dalam aktivitas kehidupan manusia di dunia ini. Pendidikan diakui sebagai kekuatan yang dapat membantu manusia mencapai kemegahan dan kemajuan peradaban. ${ }^{1}$ Manusia tidak akan dapat berkembang dan mengembangkan kebudayaannya secara sempurna bilamana tidak ditunjang oleh pendidikan. $^{2}$ Ditinjau dari konteks sejarah pun perkembangan pendidikan menjadi faktor utama yang menyokong

\footnotetext{
${ }^{1}$ Harun Asrohah, Sejarah Pendidikan Islam (Cet. I: Jakarta: Logos, 1990), ix.

${ }^{2}$ Samsul Nizar, Sejarah Pendidikan Islam Menelusuri Jejak Sejarah Pendidikan Era Rasulullah Sampai Indonesia (Cet. I; Jakarta: Kencana Group, 2007), v.
} 
kemajuan-kemajuan peradaban manusia pada masa silam. Salah satu bukti konkret adalah peninggalan peradaban Islam yang erat hubungannya dengan kemajuan pendidikan Islam itu sendiri, seperti kejayaan Islam pada periode klasik telah banyak meninggalkan jejak kebesaran Islam baik di bidang ekonomi, politik, intelektualisme, keagamaan, seni dan lain sebagainya, kesemuanya tidak terlepas dari peranan pendidikan. ${ }^{3}$

Pendidikan Islam adalah satu mata rantai yang telah memberikan sumbangsi terkait pertumbuhan dan perkembangan pendidikan secara menyeluruh. Kenyataan ini dapat dilihat bahwa sebagian besar dari metode pendidikan tinggi di Eropa dan negara-negara Barat lainnya, seperti; metode diskusi, metode tanya jawab atau bertukar fikiran, pada awalnya mereka adopsi dari konsep musyawarah dan sistem majelis taklim yang dalam Islam. ${ }^{4}$ Perkembangan sejarah pendidikan Islam tidak jauh berbeda dengan periodesasi sejarah Islam. ${ }^{5}$

Meski demikian, perlu pula ditelaah secara kritis bahwa perjalanan sejarah pendidikan Islam mulai bani Abbasiyah di belahan Timur sampai berakhirnya kekuasaan Islam di Andalusia bagian Barat Eropa, paling tidak dapat dikatakan adanya nuansa kekusaan yang memainkan peranan untuk mewujudkan kemajuan pendidikan. Manifestasi kekuasaan tersebut, nampak jelas ketika munculnya sejumlah dinastidinasti Islam yang rekam historisnya banyak berkontribusi dalam pengembangan sektor pendidikan, khususnya pendidikan Islam. Dari sekian dinasti yang menorehkan kemajuan peradaban Islam di bidang pendidikan, yaitu Dinasti Fatimiyah di Mesir. Berangkat dari fenomena di atas, selanjutnya tulisan ini akan menguraikan gambaran secara teoritis yang berkenaan dengan "Pendidikan Islam: Dinasti Fatimiyah di Mesir" pada batasan-batasan tertentu sebagai instrumen dialog. Besar harapan pembahasannya dapat memberikan sumbangsi pengetahuan terkhusus bagi penulis, dan para pemerhati sejarah agar senantiasa mengerti terkait pentingnya sejarah pendidikan Islam.

\footnotetext{
${ }^{3}$ Harun Asrohah, Sejarah Pendidikan Islam, ix.

${ }^{4}$ Bahaking Rama, Sejarah Pendidikan Islam Pertumbuhan dan Perkembangan Pada Masa Awal(Cet.I; Makassar: Alauddin Press, 2012), 5.

${ }^{5}$ Haidar Putra Daulany dan Nugraha Pasa, Pendidikan Islam Dalam Lintas Sejarah (Cet. I; Jakarta: Kencana Prenada Group, 2013), 12.
} 


\section{Pembahasan}

\section{Sejarah Berdirinya Dinasti Fatimiyah di Mesir}

Konstelasi dalam bidang politik yang terjadi dikalangan umat Islam mulai akhir zaman Dinasti Umayyah, kemudian memuncak di zaman Dinasti Abbasiyah, memberikan ruang bagi daerah-daerah yang jauh dari pusat pemerintahan di Damaskus maupun di Bagdad, berusaha untuk melepaskan diri dari kekusaan Khalifah pusat. Sehingga bermunculan dinasti-dinasti kecil yang melakukan independensi pemerintahan. ${ }^{6}$ Salah satu dari dinasti yang melepaskan diri dari kekuasaan Dinasti Abbasiyah yaitu dinasti Fatimiyah. Ubaidillah AlMahdi merupakan pelopor yang memiliki andil besar terkait berdirinya Dinasti Fatimiyah pada tahun 909 M. ${ }^{7}$ Dinasti Fatimiyah adalah Dinasti Syi'ah yang berkuasa dari tahun 909 M sampai dengan tahun $1171 \mathrm{M}$., atas dasar legitimasi klaim keturunan Nabi lewat Fahtimah dan Ali bin Abi Thalib dari Ismail anak Jafar Sidik, keturunan keenam dari Ali bin Abi Thalib. Dinasti ini didirikan sebagai tandingan bagi penguasa dunia muslim saat itu yang terpusat di Bagdad, yaitu Bani Abbasiyah. Wilayah kekuasaan Dinasti Fatimiyah meliputi Afrika Utara, Mesir, dan Suriah. Berdirinya Dinasti Fatimiyah dilatarbelakangi oleh melemahnya Dinasti Abbasiyah. $^{8}$

Dinasti Fatimiyah mengalami puncak kejayaan pada masa kepemimpinan khalifah Al-Azis. Kebudayaan Islam berkembang pesat pada masa Dinasti ini, ditandai dengan berdirinya Masjid Al-Azhar yang sekarang terkenal dengan nama Universitas Al-Azhar. Masjid ini berfungsi sebagai pusat pengkajian Islam dan ilmu pengetahuan. Danasti Fatimiyah berakhir setelah Al-Adid, selaku khalifah terakhir Dinasti Fatimiyah jatuh sakit. ${ }^{9}$ Terjadinya krisis dalam lingkup dinasti, mulai dari konflik internal antar umat Islam, kondisi politik yang tidak stabil telah menghancurkan ekonomi rakyat, dan adanya rongrongan Pasukan Salib dan Yerusaleem mengancam kota Kairo pada tahun 1167 M., telah

${ }^{6}$ Harun Nasution, Islam Ditinjau Dari Berbagai Aspeknya (Cet. V; Jakarta: UIPers, 1985), 70-71.

${ }^{7}$ Samsul Munir Amin, Sejarah Peradaban Islam (Cet. III; Jakarta: Amzah, 2013), 254.

${ }^{8}$ Asriati Amliyah, "Eksitensi Pendidikan Islam di Mesir pada Masa Daulah Fatimiyah: Lahirnya Al-Azhar, Tokoh-Tokoh Pendidikan pada Masa Daulah Fatimiyah dan Pengaruhnya Terhadap Dunia Islam”, Lentera Pendidikan 16, no. 1 (Juni 20013), 3.

${ }^{9}$ Samsul Munir Amin, Sejarah Peradaban Islam, 254. 
menambah daftar kekacauan Dinasti Fatimiyah. Meskipun kekacauan tersebut dapat di atasi oleh Salahuddin al-Ayyubi pada tahun $1771 \mathrm{M}$ dengan memakzulkan (menurunkan) khlifah terakhir Dinasti Fatimiyah, kemudian mendirikan Dinasti Ayyubiah. ${ }^{10}$

Dari penjabaran uraian tersebutkan di atas, peling tidak ada beberapa hal yang dapat dipahami. Pertama, terbentuknya Dinasti Fatimiyah di Mesir, pada awalnya disebabkan oleh adanya konstelasi politik yang terjadi dalam Dinasti Abbasiyah selaku payung kepemimpinan umat Islam pada saat itu. Kedua, menjelaskan bahwa Dinasti Fatimiyah mempunyai kontribusi dalam pembentukan peradaban Islam, khususnya pada sektor pembangunan pendidikan, kenyaataan ini dapat dilihat dari peninggalan sejarah seperti; Masjid AlAzhar, yang memiliki fungsi sebagai tempat pengkajian Islam dan pengembangan ilmu pengetahuan. Ketiga, mengungkapkan penyebab berakhirnya Dinasti Fatimiyah, secara substansi memiliki kesamaan dinasti-dinasti sebelumnya, yakni disebkan oleh faktor ketidak stabilan politik atau terjadinya perebutan kekusaan antar umat Islam.

\section{Lembaga Pendidikan Islam pada Masa Dinasti Fatimiyah di Mesir}

Tidak dapat dipungkiri bahwa lembaga pendidikan memiliki peranan dalam proses pengembangan pendidikan. Lembaga pendidikan, bukan hanya sebagai tempat pertemuan, tetapi sekaligus menjadi basis pengkajian ilmu pengetahuan. Misalnya lembaga pendikan Islam, bila meretrospekstif sejarah pembangunan pendidikan yang pernah digalang oleh Rasulullah saw, menjadikan Masjid ${ }^{11}$ sebagai tempat pembelajaran tentang niali-nilai dasar ajaran agama Islam. Dalam perkembangan selanjutnya, lembaga pendidikan Islam tidak hanya terpusat di Masjid semata, melainkan ada beberapa lembaga-lembaga baru pendidikan yang dibentuk, dan memiliki fungsi yang cukup kompleks untuk pengembangan pendidikan Islam berdasarkan tingkat kebutuhan pendidikan pada masa dinasti yang berkuasa. Kondisi ini juga dilihat

\footnotetext{
${ }^{10}$ Saleh Patuhena, dkk., Sejarah Islam Klasik(Cet. I; Makassar: Ulauddin Press, 2009), 131.

${ }^{11}$ Masjid dapat dianggap sebagai lembaga ilmu pengetahuan yang tertau dalam Islam, pembangunannya sudah dimulia dari sejak zaman Nabi dan tersebar keseluruh negeri Arab bersamaan dengan berkembangnay Islam di berbagai pelosok negerti tersebut, dalam masjid inilah berlangsungnya pengajaran al-Qur'an dan dasar-dasar agama Islam pada masa Rasulullah. Lihat Asma Hasan Fahmi dalam Samsul Nizar, Sejarah Pendidikan Islam: Menelusuri Jejak Sejarah Pendidikan Era Rasulullah Sampai Indonesia (Cet. I; Jakarta: Kencana, 2007), 9.
} 
pada era Dinasti Fatimiyah, mengingat teradapat beberapa lembaga yang dijadikan pusat pengembangan pendidikan Islam antara lain:

\section{Masjid dan Istana}

Pada masa dinasti ini, khalifah selaku pemimpin mengumpulkan para penulis di istana untuk menyalin buku-buku seperti: Al-Qur'an, Hadits, Fiqih, sastra hingga ilmu kedokteran. Ia juga memberikan penghargaan khuss bagi para ilmuwan dan menugaskan mereka menjadi imam di Masjid Istana. Tinggi perhatian pemerintah terhadap ilmu pengetahuan, sehingga kebutuhan untuk penylinan naskah tersebut pun tersedia semisal tinta dan kertas. Selain itu, Masjid juga menjadi tempat berkumpulan ulama fiqih khususnya ulama yang menganut mazhab Syi'ah Ismailiyah termasuk juga wajir dan hakim. Mereka dikumpulkan oleh khalifah untuk membuat buku tentang mazhab Syi'ah Ismailiyah yang akan diajarkan kepada masyarakat. ${ }^{12}$

\section{Perpustakaan}

Selain Masjid dan Istana, pada masa Dinasti Fatimiyah perpustakaan juga memiliki peranan sebagai lembaga pengembangan pendidikan dalam hal penyebaran akidah Syi'ah dikalangan masyarakat. Untuk itu, para khalifah dan wajir memperbanyak pengadaan berbagai buku dan ilmu pengetahuan sehingga perpustakaan istana menjadi perpustakaan yang terbesar pada masa itu. Perpustakaan yang terbesar yang dimiliki Dinasti Fatimiyah dinamakan "Dar'al 'Ulum" yang masih memiliki keterkaitannya dengan perpustakaan "Baitul Hikmah". Perpustakaan ini didirikan oleh Khalifah Fathimyah Al-Azis pada tahun 975-996 M. Konon berisi tidak kurang dari 100.000 volume, bahkan boleh jadi sebanyak 600.000 jilid buku. ${ }^{13}$

\section{Dar al-'Ilm}

Di dalam perkembangan berikutnya, pemerintahan Dinasti Fatimiyah tepanya pada bulan Jumadil Akhir sekitar tahun 1005 M., atas dasar usulan perdana menterinya Ya'kub bin Khilis, Khalifah al-Hakim mendirikan lembaga pendidikan dengan sebutan Jamiah Ilmiyah Akademi (lembaga riset) seperti akademi-akademi lain yang ada di Bagdad maupun belahan dunia lain. Lembaga ini kemudian diberi nama Dar al Hikmah. Di lembaga inilah berkumpul para ahli fiqih, astronomi,

\footnotetext{
${ }^{12}$ Suwito, ed., Sejarah Sosial Pendidikan Islam (Cet. II; Jakarta: Kencana Prenada Media Group, 2008), 124-125.

${ }^{13}$ Suwito, ed., Sejarah Sosial Pendidikan Islam...,126.
} 
dokter, dan ahli nahwu dan bahasa untuk mengadakan penelitian ilmiah. Para cendikawan tersebut, belajar al-Qur'an, astronomi, tata bahasa, leksikografi dan ilmu kedokteran dan lain sebagainya. Sehingga pada tahun 403 H., Khalifah al-Hakim mulai mengadakan majelis pertemuan rutin yang dihadiri oleh para ahli kesehatan, mantik, kedokteran, dan bersama-sama untuk mengkaji berbagai masalah. ${ }^{14}$

Uraian tentang lembaga pendidikan pada masa Dinasti Fatimiyah di atas, menegaskan beberapa hal yang dapat dipahami. Pertama, lembaga pendidikan dijadikan sebagai basis pengembangan pendidikan pada pemerintahan Dinasti Fatimiyah, secara substansi hampir sama dengan bentuk lembaga pendidikan pada dinasti-dinasti sebelumnya, yakni tetap berpijak pada Masjid dan Istana sebagai pusat belajar. Kedua, menguraikan bahwa fungsi lembaga pendidikan Islam pada masa Dinasti Fatimiyah terutama Masjid dan perpustakaan, cenderung digunakan untuk mengembangkan konsep keilmuan bermazhab Syi'ah. Ketiga, menggambarkan bahwa pengembangan ilmu pengetahuan pada masa Dinasti Fatimiyah dapat dikatakan sudah dilakukan dengan sistematis, terlihat dari upaya khalifah membentuk lembaga pendidikan yang khusus untuk menelaah dan mengkaji setiap masalah dengan pendekatan-pendekatan ilmiah.

\section{Perkembangan Ilmu Pengetahuan Pada Masa Dinasti Fatimiyah di Mesir}

Sumbangsi Dinasti Fatimiyah dalam ilmu pengetahuan tidak sebesar sumbangan Dinasti Abbasiyah di Bagdad dan Dinasti Umayyah di Spanyol. Masa ini kurang produktif dalam menghasilkan karya tulis dan ulama besar kecuali dalam jumlah kecil, sekalipun banyak di antara khalifah dan para wajir menaruh perhatian dan penghormatan kepada ulama, ilmuwan dan pujangga. Dalam perkembangannya, para ulama mengklasifikasi ilmu pengetahuan di masa Dinasti Fatimiyah ke dalam beberapa bidang ilmu pengetahuan, antara lain:

\section{Bahasa dan Sastra}

Di antara ulama yang terkenal tentang bahasa dan sastra adalah Abu Tohir An-Nahwi, abu Ya'qub Yusuf bi Ya'qub, Abu Hasan Ali bin Ibrahim yang telah mengarang beberapa buku sastra. ${ }^{15}$

\footnotetext{
${ }^{14}$ Suwito, ed., Sejarah Sosial Pendidikan Islam...,129-130.

${ }^{15}$ Suwito, ed., Sejarah Sosial Pendidikan Islam..., 131-132.
} 


\section{Kedokteran}

Dinasti Fatimiyah sangat memberikan perhatian yang besar pada ilmu kedokteran. Dinasti ini menempatkan posisi dokter ditempat yang tinggi dengan memberikan upah dan kedudukan yang terhormat. Lazimnya para dokter ini pula menguasai ilmu filsafat serta bahasa asing khususnya bahasa Yunani. Tokoh kedokteran yang sangat dikenal pada Dinasti Fatimiyah seperti; abu Abdullah Muhammad bin Ahmad bin said An-Namimi yang bertempat tinggal Di Baitul Maqdis. Ia banyak menimba ilmu di negara lain, sehingga memiliki kemampuan untuk meracik obat sendiri.

\section{Syair}

Syair termasuk bidang pengetahuan yang cukup berkembang pada masa Dinasti Fatimiyah. Para penyair melakukan puji-pujian terhadap khalifah dengan menghina syair-syair ahli Sunnah, dengan pekerjaanya ini para penyair seperti; Ibnu Hani banyak mendapat imbalan dari khalifah yang berkuasa pada masa itu. Para penyair bersama khalifah berusaha untuk menyebarkan doktrin Syi'ah Ismailiyah melalui pantun dan syair.

\section{Filsafat}

Filsafat merupakan bidang pengetahuan yang berkembang pada masa Dinasti Fatimiyah. Tokoh filsafat yang terkenal pada masa dinasti ini disebut dengan Ikhwan al-Shafa. Tokok lain, yang juga berkecimpun dalam bidang filsafat di antaranya Abu Hatim al-Raji, Abu Hanifah anNu'man al-Maghriby, dan Ja'far bin Mansyur al-Yaman. Para tokoh tersebut, banyak melahirkan pemikiran dalam bentuk pemikiran filsafat, seperti; Kitab al-Buyu' dan Kitab Tharah karya Abu Hanifah anNu'man al-Maghriby, atau kitab ta'wil al zakat dan kitab Al-Jafru alAswad karya Ja'far bin Mansyur al-Yaman. ${ }^{16}$

Dari uraian di atas, dapat dipahami bahwa perkembangan pengetahuan di masa Dinasti Fatimiyah secara keseluruhan sudah berkembang dengan cukup baik sebagai bentuk tindak lanjut dari pengembangan pendidikan yang pernah dilakukan oleh rezim sebelumnya, meskipun ada tendensi mazhab negara yang turut mempengaruhi proses pengembangan pendidikan.

\footnotetext{
${ }^{16}$ Suwito, ed., Sejarah Sosial Pendidikan Islam...,133.
} 


\section{Kedudukan Al-Azhar dalam Pengembangan Pendidikan Islam Pada Masa Dinasti Fatimiyah di Mesir}

Al-Azhar merupakan lembaga pendidikan bertaraf internasional yang berpusat di Kairo, Mesir. Kemampuannya menghadapi perubahan dan menjawab tantangan telah terbukti. al-Azhar mula-mula didirikan sebagai Masjid oleh panglima Fatimiyah, Jenderal Jauhar as-Siqili pada tanggal 24 Jumadil Ula 359 H/970 M dan selesai pembangunannya pada bulan Ramadhan $361 \mathrm{H}$, setelah Mesir pada tahun $354 \mathrm{H} / 969 \mathrm{M}$ secara penuh dikuasainya. Menurut sumber yang dikutip Van Houve dalam Ensiklopedi Islam menyebutkan bahwa al-Azhar berdiri pada tahun 359 H/970 M. ${ }^{17}$ Pada masa Dinasti Fatimiyah, al-Azhar menjadi corong propaganda kekusaan kekhalifahan, sekaligsus sebagai alat penyebaran doktrin ajaran Syi'ah. Selain itu, ada beberapa hal yang mendasar untuk melihat eksistensi al-Azhar sebagai lembaga tinggi yang erat hubungan dengan pengembangan pendidikan Islam pada masa Dinasti Fatimiyah antara lain:

\section{Sistem Pengajaran di Al-Azhar}

Di dalam proses pengajaran, sistem yang gunakan Al-Azhar terbagai menjadi empat kelas, meliputi: Pertama, kelas umum yang diperuntukan bagi orang-orang yang datang ke al-Azhar untuk mempelajari al-Qur'an dan penafsirannya. Kedua, kelas para mahasiswa Universitas al-Azhar kuliah dengan para dosen yang ditandai dengan mengajukan pertanyaan dan mengkaji jawabannya. Ketiga, kelas Darul Hikam, kuliah formal ini diberikan oleh para mubalig seminggu sekali pada hari Senin yang dibuka untuk umum dan pada hari Kamis dibuka khusus untuk mahasiswa pilihan. Keempat, kelas nonformal, yakni kelas untuk pelajar wanita. ${ }^{18}$

\section{Kurikulum Pengajaran al-Azhar}

Pada mulanya pengajaran di universitas al-Azhar sama dengan pelaksanaan pengajaran di institusi pendidikan lain, yaitu metode berhalaqah (melingkar); seorang pelajar bebas memilih guru dan

${ }^{17}$ Asriati Amliyah, "Eksitensi Pendidikan Islam di Mesir pada Masa Daulah Fatimiyah: Lahirnya Al-Azhar, Tokoh-Tokoh Pendidikan pada Masa Daulah Fatimiyah dan Pengaruhnya Terhadap Dunia Islam", Lentera Pendidikan 16, no. 1 (Juni 20013), 5.

${ }^{18}$ Abuddin Nata, Sejarah Islam Klasik: Peda Periode Klasik dan Pertengahan (Cet. III; Jakarta: PT Rajagrafindo persada, 2013), 91-96. 
berpindah sesuai dengan kemauan. Di samping itu, metode lain yang sangat dikembangakan dalam proses pembelajaran antar siswa yaitu metode diskusi. Seorang guru berperan sebagai fasilitator utnuk memberikan penajaman terkait materi yang didiskusikan. Sedangakan kurikulum yang dipakai di al-Azhar pada mula fiqih dan al-Qur'an dan ilmu agama lainnya. Namun setelah berubah menjadi universitas mulaillah memasukan disiplin ilmu umum, seperti kedokteran, ilmu sejarah, ilmu hitung, logika, dan lain-lain.

\section{Peranan al-Azhar dalam mencetak Ulama}

Al-azhar sebagai lembaga pendidikan tinggi saat itu, telah banyak melahirkan tokoh ulama yang tidak lagi diragukan dari aspek keilmuannya, dan para ulama tersebut telah banyak menyumbangkan khasanah ilmu pengetahuan terutama yang berhubungan dengan nuansanuansa keIslaman. Di antara tokoh-tokoh ulama yang dimaksud, seperti Izauddin bin Abdissalam, Imam Subki, Jalaluddin As-Suyuti, Al-Hafis Ibnu Hajar Asqolani, yang karya monumentalnya masih dapat dipelajari dan disaksikan sampai sekarang ini. Dari penjabaran diatas, dapat dipahami bahwa al-Azhar selaku lembaga pendidikan, telah memainkan peranan penting dalam pengembangan pendidikan Islam, meskipun awal terbentuknya hanya dijadikan sebagai penunjang untuk pengembangan ajaran-ajaran Syi'ah. Akan tetapi yang paling terpenting adalah eksistensi al-Azhar sebagai lembaga pendidikan tinggi Islam Dinasti Fatimiyah telah menunjukan fakta sejarah bahwa Islam telah mempunyai akar kemajuan-kemajuan pendidikan, khususnya dalam pendidikan Islam.

\section{Penutup}

Berangkat dari beberapa uraian sebelumnya, kaitanya dengan pembahasan tentang pendidikan Islam: Dinasti Fatimiyah di Mesir, maka dapat disimpulkan bahwa Dinasti Fatimiyah adalah Dinasti Syi'ah yang didirikan oleh Ubaidillah Al-Mahdi. Dinasti ini berkuasa dari tahun 909 M sampai dengan tahun 1171 M., atas dasar legitimasi klaim keturunan Nabi lewat Fahtimah dan Ali bin Abi Thalib dari Ismail anak Jafar Sidik. Dinasti ini didirikan sebagai tandingan bagi penguasa dunia muslim saat itu yang terpusat di Bagdad, yaitu Bani Abbasiyah. Wilayah kekuasaan Dinasti Fatimiyah meliputi Afrika Utara, Mesir, dan Suriah. Berdirinya Dinasti Fatimiyah dilatarbelakangi oleh melemahnya Dinasti Abbasiyah. Pada masa Dinasti Fatimiyah, lembaga pendidikan 
yang digunakan sebagai basis pengembangan pendidikan terdiri dari; Masjid, Istana, Perpusakaan dan Dar al-'Ilm atau biasa disebut Jamiah Ilmiyah Akademi (lembaga riset). Perkembangan ilmu pengetahuan pada masa Dinasti Fatimiyah meliputi beberapa bidang ilmu seperti; Bahasa dan Sastra, Ilmu Kedokteran, Syair dan Filsafat. Berkenaan dengan hal tersebut, universitas Al-azhar merupakan lembaga pendidikan tinggi, sekaligus menjadi bukti sejarah peradaban Dinasti Fatimiyah dalam pengembangan pendidikan, dan sampai sekarang menjadi kiblat pendidikan yang bernuansa Islam. Dari sisi pengajarannya, al-Azhar pada masa Dinasti Fatimiyah dilaksanakan dengan sistem kelas. Metode pengajaran menggunakan metode berhalaqah dan metode diskusi. Sedangkan kurikulum yang dipakai di al-Azhar pada mula fiqih dan al-Qur'an dan ilmu agama lainnya.

\section{DAFTAR PUSTAKA}

Amin, Samsul Munir. Sejarah Peradaban Islam. Cet. III; Jakarta: Amzah, 2013.

Amliyah, Asriati. "Eksitensi Pendidikan Islam di Mesir pada Masa Daulah Fatimiyah: Lahirnya Al-Azhar, Tokoh-Tokoh Pendidikan pada Masa Daulah Fatimiyah dan Pengaruhnya Terhadap Dunia Islam”, Lentera Pendidikan 16, no. 1 (Juni 20013):

Asrohah, Harun. Sejarah Pendidikan Islam. Cet. I: Jakarta: Logos, 1990.

Daulany, Haidar Putra dan Nugraha Pasa. Pendidikan Islam Dalam Lintas Sejarah . Cet. I; Jakarta: Kencana prenada group, 2013.

Nasution, Harun. Islam Ditinjau Dari Berbagai Aspeknya. Cet. V; Jakarta: UI-Pers, 1985.

Nata, Abuddin. Sejarah Islam Klasik: Peda Periode Klasik dan Pertengahan. Cet. III; Jakarta: PT Rajagrafindo Persada, 2013.

Nizar, Samsul. Sejarah Pendidikan Islam Menelusuri Jejak Sejarah Pendidikan Era Rasulullah Sampai Indonesia. Cet. I; Jakarta: Kencana Group, 2007.

Patuhena, Saleh, dkk. Sejarah Islam Klasik. Cet. I; Makassar: Ulauddin Press, 2009.

Rama, Bahaking. Sejarah Pendidikan Islam Pertumbuhan dan Perkembangan Pada Masa Awal. Cet.I; Makassar: Alauddin Press, 2012.

Suwito, ed. Sejarah Sosial Pendidikan Islam. Cet. II; Jakarta: Kencana Prenada Media Group, 2008. 
Jurnal Ilmiah "Kreatif" Vol. 18 No. 1, Januari 2020

"Jurnal Studi Pemiß̧iran Pendidikan Agama Islam" 